\title{
DETERMINANT OF JOB SATISFACTION WITH BURNOUT AS A MEDIATION AND TEAMWORK AS A MODERATION : STUDY IN BANK INDONESIA
}

\author{
Teuku Munandar, Said Musnadi and Sorayanti Utami \\ Department of Management, Universitas Syiah Kuala, Indonesia \\ http://doi.org/10.35409/IJBMER.2020.3151
}

\begin{abstract}
This study aims to examine the effect of technostress on job satisfaction by involving the role of burnout as a mediator and teamwork as a moderator. The population of this study is all Bank Indonesia employees. The selected sample is the employees who have been working more than two years and use information technology systems both software developed by BI and hardware such as smart phones and laptops. The sampling technique used is random sampling. The analysis uses Partial Least Square (PLS) as a statistical test technique. The result shows that technostress has a negative effect on job satisfaction, technostress has a positive effect on burnout, burnout has a negative effect on job satisfaction, burnout mediates the influence between technostress and job satisfaction, and teamwork moderates the effect of technostress and job satisfaction. These results figure that the higher psychological pressure faced by individuals due to the use of technology can reduce the level of individual job satisfaction. This result also means that individuals who experience psychological pressure due to the use of technology have an impact on increasing mental and psychological fatigue (burnout) of individuals. Mental and psychological fatigue cause individuals to be apathetic and reduce their level of satisfaction with the work done. But then, teamwork can reduce the negative effect of technostress on job satisfaction. These findings strenghten the previous theories especially the causality ones. It contributes to the realm of science especially in human resource management field, and can be a reference for practical managers especially in the Bank Indonesia as the research object. The originality lies in the combination of causality models, uses SEM-PLS as an analysis tool, and the new object. The limitation resides in the amount of variables that are only three, with one object
\end{abstract}

Keyword: techno stress creators, job satisfaction, burnout, teamwork.

\section{INTRODUCTION}

Facing the increasingly business competition, ICT (Information and Communication Technology) implementation is a necessity for a company to continue to exist and compete with competitors. However, the implementation of ICTs with a high level of complexity can actually affect the productivity of workers (Tarafdar et al., 2007); (Khallash and Kruse, 2012); (Suh and Lee, 2017); (Tarafdar, Cooper and Stich, 2017). This happens because a feeling of inability to overcome or difficulties in dealing with the complexity of a new technology. Technological developments can also be a threat to workers. Threats arise from other more competent 


\section{International Journal of Business Management and Economic Review}

Vol. 3, No. 01; 2020

ISSN: 2581-4664

individuals or even the technology itself which can replace their roles and positions within a company (Srivastava, Chandra and Shirish, 2015)

Technostress phenomenon occurs not only in the private sector, but also often found in the public sector, both government agencies and other state institutions. In 2019, Bank Indonesia has simultaneously implemented an information system transformation namely BIMASAKTI (Bank Indonesia Towards Integrated Information Systems). The BIMASAKTI program aims to integrate the entire information system into a single unit to make it easier to integrate data for decision making. BIMASAKTI consists of 5 (five) main information systems namely Electronic Data Warehouse (EDW), Enterprise Resource Planning (ERP), Human Resource Information System (HRIS), Core Banking System (CBS), and Front Office Middle Office Back Office (FOMOBO). The five systems change $90 \%$ of all old systems used and involve all elements of the employee and change the business process work. Implementation of BIMASAKTI is a demand for central banks to be able to adapt to global changes and be able to carry out good governance practices well.

A pre-elementary surveythat was conducted at Bank Indonesia resulted that of 15 employees showing symptoms of technostress. The survey results show that the level of technostress of employees is quite high with an average of 3.57 (enough). More specifically, the majority of employees feel that the use of technology increases the amount of work they have to do (techno-overload), sacrifices personal time to do work (techno-invasion), increases the complexity of performing tasks (techno-complexity), and believes that technological change will continuously happening (techno-uncertainty). Meanwhile, employees' perceptions of technological threats to their work are relatively low (techno-insecurity).

In addition, the use of smart phone-based ICT devices causes the lives of employees to be invaded. (Brooks and Califf, 2017) empirically affirmed the effect of the use of social media on employee performance. The result of his research indicated that the use of social media influences techonstress and negatively influences performance especially in areas of work with low characteristics. This study provided an evidence that the use of social media triggers technostress and has the potential to reduce performance levels. The work day tends to expand and enter all other areas of life. All this ultimately leads to a loss of individual productivity (Tarafdar, Tu and Ragu-Nathan, 2014). In addition, the inability to adapt to ICTs can have an impact on job satisfaction (Tarafdar, Tu and Ragu-Nathan, 2014); (Alleyne, 2012); (Saganuwan, Ismail and Ahmad, 2015); (Khan, Rehman and Réhman, 2013).

From the standpoint of technostress psychology is proven to reduce individual job satisfaction (Ragu-Nathan et al., 2008). However, how is the pattern of relationships formed between the two? The question becomes important to answer because the existing literature has not succeeded in uncovering specific pathways that connect technostress and job satisfaction. (Francis and Popoola, 2013) found that technostress is a determinant of job burnout. (Srivastava, Chandra and Shirish, 2015) also found that technostress can also affect job outcomes both positive (job engagement) and negative (job burnout). (Khedhaouria and Cucchi, 2019) also found a positive influence between technostress and burnout. Burnout is simply defined as the syndrome of emotional exhaustion and loss of personal achievement (Affleck, 1996). Based on these findings the researchers suspect that burnout can be a bridge to clarify the pattern of conceptual relationships between technostress and job satisfaction.

In order to fill the existing gaps, this study seeks to explore the pathway that connects 


\section{International Journal of Business Management and Economic Review}

Vol. 3, No. 01; 2020

ISSN: 2581-4664

technostress to job satisfaction through burnout. Several previous studies have proven the existence of technostress and tested the determinants and consequences of the phenomenon. However, from an organizational point of view, individuals certainly try to avoid the phenomenon of technostress that disturbs their productivity. Furthermore, this study aims to find variables that are able to reduce the negative relationship between technostress and job satisfaction.

(Griffin, Petterson and West, 2001) asserted that effective teamwork can enhance motivation and increase job satisfaction. Teamwork generally contains a set of interdependent employees who work cooperatively to achieve a common goal (Parker and Wall, 1998). The literatures have described that teamwork positively influences job satisfaction (Khuong and Tien, 2013). Some researchers have also found that high levels of team work can increase employee job satisfaction and encourage employees to try harder in carrying out work (Mafini and Pooe, 2013); (Nickerson and Nagle, 2005); (Sumer and Knight, 2001). When effective teamwork can increase job satisfaction, then the variable is expected to reduce the negative influence between technostress on job satisfaction. The negative influence of technostress on job satisfaction is predicted to be influenced by the level of teamwork. In order to facilitate the limitations of previous research, this study seeks to explore teamwork relationships as a moderator in the path of conceptual relationship technostress and job satisfaction.

This study aims to fill the research gap (gap research) on the topic of technostress. Previous research has proven to have a negative influence between technostress and job satisfaction. However, there are no studies that specifically analyze the pattern of relationships formed between the two. The first novelty of this study is the identification of variables that connect technostress and job satisfaction. In addition, previous research has also succeeded in proving the existence of technostress and tested the determinants and consequences of the phenomenon. However, from an organizational point of view, individuals certainly want to avoid the phenomenon of technostress that disturbs their productivity. The second novelty of this study is to analyze variables that are able to reduce the negative relationship between technostress and job satisfaction in Bank Indonesia.

\section{LITERATURE REVIEW}

Job satisfaction

Job satisfaction is an area that has high complexity and is a serious concern for the majority of executives in managing their employees. (Furnham et al., 2002) defined job satisfaction as an employee's perception of the work done. Job satisfaction is the end result that is expected to be felt from carrying out an activity or job. This is in line with the opinion of(Klassen, Usher and Bong, 2010) which stated that job satisfaction is a feeling that arises from doing daily work. (Morris and Venkatesh, 2010) defined job satisfaction as an amount of increased emotional pleasure in the form of deep job satisfaction (which is in line with professional values) of a job. (Khan, Rehman and Réhman, 2013) stated that job satisfaction is a positive or negative emotional feeling about the work done. In line with (Aydogdu and Aş1kgil, 2011) which stated that job satisfaction is described as people's attitudes towards their work.

(Herzberg, 1974) put forward the Two Factor Theory (Two Factor Theory). First, factors that cause satisfaction are called motivators and factors that cause dissatisfaction are referred to as personal factors (hygiene factors). In addition to these factors, job satisfaction is also 


\section{International Journal of Business Management and Economic Review}

Vol. 3, No. 01; 2020

ISSN: 2581-4664

influenced by the use of information systems (Fuglseth and Sørebø, 2014), work overload (Tarafdar et al., 2007), technological change (Muhammadsyah, Nasir and Faisal, 2019), leadership effectiveness, organizational support, and work environment (work environment) (Wani, Adam and Majid, 2018), emotional, mental and physical disabilities (Patience, 2012), employee commitment and competence (Marhayani, Musnadi and Ibrahim, 2019), teamwork (Khuong and Tien, 2013); (Griffin, Petterson and West, 2001).

\section{Burnout}

Burnout was first defined by (Freudenberger, 1974) as a syndrome of emotional exhaustion, disappointment, and can cause deterioration in health (Amoo and Fatoye, 2008). Burnout is a condition of emotional, mental, and physical fatigue caused by excessive and prolonged stress (Patience, 2012). (Affleck, 1996) defined burnout as an emotional fatigue syndrome, depersonalization, and a loss of personal achievement. Burnout occurs when individuals are overwhelmed and unable to meet requests from superiors, unable to cope with problems, and difficult to gather energy to do work (Francis and Popoola, 2013).

(Maslach, Schaufeli and Leiter, 2001) defined burnout as a psychological symptom of a prolonged response to chronic emotions and interpersonal stress on a job. The definition is widely used as a reference by various literatures related to burnout. (Maslach, Schaufeli and Leiter, 2001) divided burnout into three main dimensions namely, fatigue, cynicism, and inefficiency. Fatigue reflects the perceived individual pressure. Dimension fatigue refers to feeling excessive and depleted of one's physical and emotional resources. Cynicism reflects dimensions in the context of interpersonal relationships. Cynicism can be interpreted as a negative, unfeeling response, or separate response to various aspects of work. The inefficiency dimension describes the self-evaluation dimension of burnout. Inefficiency refers to the feelings of individuals who doubt their competence, lack of achievement, lack of work productivity. (Maslach, Schaufeli and Leiter, 2001) documented the variety of literature and disaggregated the factors that influence burnout. Two main factors that can empirically influence burnout are Situational Factors and Individual Factors. Situational factors are factors related to working conditions. Individual factors are factors related to individual characteristics.

(Francis and Popoola, 2013) found evidence that descriptive technostress hasa positive influence on burnout. Previous studies also found similar evidence to show that burnout can be caused by technostress and excessive workload (Francis and Popoola, 2013); (Srivastava, Chandra and Shirish, 2015); (Khedhaouria and Cucchi, 2019). In theory, the majority of literatures showed that burnout has a close association with job satisfaction (Halbesleben and Buckley, 2004); (Yang, 2010); (Khan, Rehman and Réhman, 2013); (Francis and Popoola, 2013); (Khalatbari, Ghorbanshiroudi and Firouzbakhsh, 2013); (Khamisa et al., 2017); (Tarcan et al., 2017) . Previous studies had found evidence that negative feelings generated at work cause a tendency for job dissatisfaction. (Ibrahim and Yusra, 2016) also explained that conflicts that occur in work and family are able to trigger negative feelings that cause a tendency to decrease job satisfaction.

Researchers suspected that burnout is one of the variables that can potentially explain the effect of technostress creators on job satisfaction (Francis and Popoola, 2013); (Srivastava, Chandra and Shirish, 2015); (Khedhaouria and Cucchi, 2019). Excessive use of technology and attitudes of inability to adapt to technological change will cause negative feelings that trigger emotional exhaustion, depersonalization, and decreased performance. The ongoing fatigue will have an impact on employee loyalty to the job and reduce the level of job satisfaction. 


\section{International Journal of Business Management and Economic Review}

Vol. 3, No. 01; 2020

ISSN: 2581-4664

The symptoms of burnout are seen in physical and emotional exhaustion. Physical symptoms include physical fatigue, pain, and sleep problems, while emotional symptoms include disappointment at work, loss of sense or meaning at work, feelings of cynicism about the organization or client, feelings of helplessness, frustration, anger, feelings of depression, and feeling alienated (Francis and Popoola, 2013). Factors that cause burnout include excessive workload, low recognition and appreciation for work performed, lack of success and progress on the job, poorly designed work, too many emotional demands from colleagues, and difficult or ungrateful clients (Bhanugopan and Fish, 2006); (Brookings et al., 1985); (Rosenberg and Pace, 2006).

\section{Technostress Creators}

The concept of technostress is explained by the transaction theory of stress proposed by (Lazarus, 1966). This theory described the stress phenomenon as a combination of demand conditions that cause stress and individual responses to it (Tarafdar, Pullins and Ragu-Nathan, 2014). In this case the use of ICT. The theory forms the basis for the theoretical conceptualization of the technostres phenomenon. Technostress was developed by (Brod, 1984) to describe the pressure caused by the inability to cope with the demands of computer use in organizations (Wang, Kakhki and Uppala, 2017). Technostress is a modern phenomenon of the use of information technology and computers (Ayyagari, Grover and Purvis, 2011).

Technostress triggers negative effects on attitudes, thoughts, behavior, and human psychology that are direct or indirect results of the use of technology (Weil, Rosen and Wugalter, 1990). Simply put, technostress occurs after using ICT. (Wang, Shu and TU, 2008) stated that technostress occurs due to the inability of individuals to manage new computer technology. Technostress is shown by anxious and anxious attitudes when studying and using computer technology.

The implementation of technology carried out by organizations aims to improve the performance of individuals and organizations. The problem occurs because not all individuals can accept technology and use it well. Individuals find it difficult to change the way the old work to the new work that uses ICT (Brod, 1982). Inability to operate technology encourages work stress (Chen, 2015). (Chang, 2006) stated that when companies implement new business systems, resistance to the technology emerges. This happens because of the lack of business benefits felt by individuals who use the new system. As a result, when the new system does not function as expected, they experience technostress.

Other facts showed that the increasingly complex operation of ICT makes users frustrated with the number of features and how to use these features(Ayyagari, Grover and Purvis, 2011). (Åborg and Billing, 2003) also mentioned that users who interact with unreliable ICTs will experience frustration and tension. They feel that ICTs do not provide significant business benefits. This happens because of the emergence of resistance when using new technology (Chang, 2006).

According to (Amoako-Gyampah, 2007), when professionals are more involved in planning, implementing, and training to use new technologies, they are more likely to experience low levels of technostress. This happens because they have known, studied, and been able to operate the technology first. In contrast to employees, disruptions and problems that are triggered by the use of ICTs in business processes, the roles, responsibilities of employees, and organizational culture are a significant source of stress for the workforce today (Chen, 2015).

Technostress has a negative impact. The negative impacts of technostress on employees include decreased work participation, productivity and performance, cognitive and psychological symptoms such as perception of work overload, information fatigue, computer anxiety, and dissatisfaction at work (Brod, 1984); (Weil and Rosen, 1997); (Suh and Han, 2003); (Tu, Wang and Shu, 2005). Although many studies 


\section{International Journal of Business Management and Economic Review}

Vol. 3, No. 01; 2020

ISSN: 2581-4664

have tested stress variables, technostress has not been widely studied (Ayyagari, Grover and Purvis, 2011). (Chen, 2015)and (Galluch, Grover and Thatcher, 2015) stated that although technostress has taken place globally, research efforts, especially empirical studies, are still very limited. Therefore, further testing is needed regarding the impact of Technostress.

\section{Teamwork}

Teamwork is popular in organizations because doing teamwork has the potential to improve performance and creativity, synergize the influence of each member, reduce production costs and absenteeism (Delarue et al., 2007); (Rhodes et al., 2011). Psychological literatures that extensively examined perceptions and actions stated that individuals often perceive and acknowledge situations that occur in teams as a form of team effort. This recognition triggers specialization, cognitive coordination which makes a "common cause" that occurs in the team (Sebanz, Bekkering and Knoblich, 2006). The psychological condition implies that the orientation of team members towards team goals is due to individual perceptions about the environment.

Team work can also be interpreted as a group consisting of several individuals/ employees who work together in doing work to achieve common goals (Parker and Wall, 1998). (Sundstrom, Meuse and Futrell, 1990) defined teamwork as a group where each group member shares the responsibility for achieving organizational goals. Teamwork takes many forms tailored to the needs of each organization (Janz, Colquitt and Noe, 1997). The purpose of forming teams is to create different work environments that provide individual / employee experience for working with different methods (Wall et al., 1986). The presence of team members provides psychological support which results in low negative feelings towards the work done. In forming teamwork, managers can play the role of organizing the team as desired so that shared goals can be achieved (Griffin, Petterson and West, 2001). Forming a good team is very necessary so that there is no failure in achieving the desired outcome of the company (Hackman, 1989)

Effectiveness of teamwork provides a potential benefit on outcomes achieved the employees in the organization (Parker and Wall, 1998). In the event of pressure on the use of technology that affects the mental and psychological conditions of employees, employees need social support to avoid difficulties and fatigue due to the use of complex ICTs (Galluch, Grover and Thatcher, 2015). (Yukl, 2006) stated that support from others is a strong determinant of achieving job satisfaction in a variety of work environments. (Griffin, Petterson and West, 2001) also mentioned that the use of teamwork within the organization relating to the satisfaction felt by team members.

Research by (Campion, Medsker and Higgs, 1993) stated that job satisfaction of team members is determined by several factors including the composition of the team, the processes that occur in the team, and the nature of the work done in the team. (Wang, Shu and TU, 2008) and (Kayastha, Adhikary and Krishnamurthy, 2012) found that decreasing the level of technostress on employees will have an impact on job satisfaction that is increasingly high. Based on the literature, researchers predict that the negative relationship between technostress and job satisfaction can be reduced through the effectiveness of teamwork.

\section{Hypothesis Development and Research Paradigm}

Negative emotional feelings arising from carrying out a job cause dissatisfaction with the work done (Khan, Rehman and Réhman, 2013). One of the causes of employee dissatisfaction in the company is 


\section{International Journal of Business Management and Economic Review}

Vol. 3, No. 01; 2020

ISSN: 2581-4664

related to the use of ICTs (Fuglseth and Sørebø, 2014). Dissatisfaction is shown by the mental state of individuals that reflects the perception of the use of ICT as a threat (Beaudry and Pinsonneault, 2010). In the company, employees are required to be able to carry out activities in accordance with the wishes of the company including using ICT. This causes a role stress. Role stress ultimately disrupts the ability of employees to do their jobs efficiently and effectively (Chen, 2015). Stress caused by the use of technology is called technostress (Brod, 1982). Technostress is the mental stress experienced by employees due to the use of ICT in the workplace (Weil and Rosen, 1997).

(Tarafdar et al., 2011) in his study found that technostress has a direct effect on employee satisfaction.(Fuglseth and Sørebø, 2014) stated that employees who experience high-level technostress in their environment will experience dissatisfaction with work. It was in line with the research of(Khan, Rehman and Réhman, 2013) which stated that technostress can reduce employee job satisfaction. Research (Tarafdar et al., 2011)showed that negative cognition can reduce user satisfaction with the systems and applications they use that are influenced by their ability to use ICT.

Based on the description above, the negative impact caused by technostress is employee job dissatisfaction which results in low productivity and high turnover (Alleyne, 2012). Research conducted by (Ragu-Nathan et al., 2008) and (Tarafdar et al., 2007) found that individuals who experienced technostress had lower productivity and job satisfaction. (Wang, Shu and TU, 2008) and (Kayastha, Adhikary and Krishnamurthy, 2012) found that the decrease in technostress rate on employees will have an impact on job satisfaction. In line with (Tarafdar et al., 2011) who found that technostress decreases ICT user satisfaction. It can be concluded that, the higher the level of technostress, the lower individual job satisfaction.

H1: Technostress has a negative effect on job satisfaction

Burnout can be caused by technostress and excessive workload (Francis and Popoola, 2013). Common symptoms of technostress tend to vary, including feelings of frustration, negative attitudes toward sources and systems based on new computer technology, and indifference to the needs associated with the user's computer. (Brillhart, 2004) identified four forms of technostress namely data smog, multitasking madness, computer hassles, and burnout. Smog data refers to information overload experienced by users that causes information fatigue syndrome. Multitasking madness refers to the conflict between the multitasking nature of computer systems and the limitations of the human mind. Computer hassles refer to technical problems and problems (viruses, spam, pop-up ads, etc.) caused by the use of ICTs. Finally, burnout refers to the feeling of exhaustion that results from a conflict between experiencing too much pressure and a lack of satisfaction from using ICT.

Although the benefits of ICT adoption are undoubtedly, the use of ICT generates a number of demands and challenges that result in technostress and job burnout in the workplace (Francis and Popoola, 2013). Technostress describes the pressures experienced by users as a result of multitasking applications, constant connectivity, information overload, continuous improvement of the system and the uncertainties they cause, continuous relearning, consequences of work-related insecurities, and technical problems associated with using ICT (Tarafdar et al., 2011). High technostress due to using ICTs have an impact on burnout.

Burnout is described as losing all interest and motivation for a reason. Because it is technostress. The results of research conducted by (Francis and Popoola, 2013) showed that technostress has a positive relationship with burnout. This result was in line with research conducted by (Affleck, 1996). (Kupersmith, 1992) also mentioned that technostress contributes to burnout in employees who are required to use ICT. Based on these results it can be concluded that the higher the technostress, the higher the burnout. 


\title{
International Journal of Business Management and Economic Review
}

\author{
Vol. 3, No. 01; 2020
}

ISSN: 2581-4664

Technostress arises from the increasing use of ICTs (Tarafdar et al., 2011). Technostress has symptoms in the form of feelings of fear, headaches, panic, frustration, negative attitudes towards the computer, and anger (Kupersmith, 1992). This can not be avoided because the use of technology in the company is important. Managers and staff members in organizations use company computers and software to support operational workflows and improve decision-making performance, efficiency, and productivity (Riedl et al., 2013). Technostress occurs due to the inability of individuals to manage new computer technology (Wang, Shu and TU, 2008).

Technostress is a negative consequence that has a direct or indirect impact on the user's physiological, behavioral, and psychological changes in the form of physical and emotional exhaustion (Khan, Rehman and Réhman, 2013). These negative consequences if they occur continuously will result in burnout. Burnout is a condition of emotional, mental, and physical fatigue caused by excessive and prolonged stress (Patience, 2012). Such excessive and prolonged stress can occur due to the company's demands to use ICTs that are not supported by the ability of individuals to operate them (Francis, 2013). The results of research conducted by (Kupersmith, 1992); (Affleck, 1996); and (Francis and Popoola, 2013) showed that technostress has a positive effect on burnout. That is, high stress due to the use of ICT (technostress) results in excessive emotional and physical exhaustion or what is called burnout

Individuals who experience burnout have the syndrome of emotional exhaustion, depersonalization and a loss of sense of personal achievement (Affleck, 1996). This has an impact on their job satisfaction. The inability of individuals to work optimally due to limited cognition in the use of ICT causes dissatisfaction with their work. Technostress and burnout cause negative feelings in individuals. Negative emotional feelings of employees cause feelings of dissatisfaction with their work (Khan, Rehman and Réhman, 2013). (Francis and Popoola, 2013) also mentioned that the high burnout will have an impact on the high feeling of dissatisfaction. Fatigue and powerlessness of individuals in using ICTs can threaten a person's work, relationships and health. This can reduce an individual's productivity and energy, make someone feel increasingly helpless, and hate the obligations they have to complete. This is the cause of the emergence of feelings of dissatisfaction with individual work. Based on the description it figures that the negative influence of technostress on job satisfaction is mediated by burnout.

H2: Technostress has a positive effect on burnout

H3:Burnout has a negative effect on job satisfaction

H4:Burnout mediates the influence between technostress and job satisfaction

Today, many companies rely on teamwork to achieve company goals (Griffin, Petterson and West, 2001), Including in doing work that uses ICT. The problem that arises from the use of ICT is the emergence of technostress. Technostress can occur one of which is caused by a lack of social presence (Galluch, Grover and Thatcher, 2015).(Kupersmith, 1992) also mentioned that technological innovation can have a negative impact that is causing stress among employees. Organizations need to help employees reduce technostress to strengthen their return on investment in technology and ensure the success of Organization (Chen, 2015). One way is to form a team. Employees will feel helped by the help of a teammate. (RaguNathan et al., 2008) stated that the step to reduce technostess is with literacy facilities. Literacy facilitation refers to establishing close relationships with information systems departments and encouraging ICT knowledge sharing among colleagues.

Individuals who experience technostress show physical and emotional fatigue (Weil and Rosen, 1997). This will have an impact on reducing job satisfaction. Therefore, a solution is needed to avoid a 


\section{International Journal of Business Management and Economic Review}

Vol. 3, No. 01; 2020

ISSN: 2581-4664

decrease in job satisfaction by implementing teamwork. Implementation of teamwork provides potential benefits to the outcomes achieved by employees in the organization (Parker and Wall, 1998). In companies, individuals are required to use the latest technology. This puts pressure on the individual. Individuals need social support to avoid difficulties and fatigue due to complicated use of ICTs (Galluch, Grover and Thatcher, 2015). (Yukl, 2006) states that support from others is a strong determinant of achieving job satisfaction in a variety of work environments. (Griffin, Petterson and West, 2001) also mentions that the use of teamwork within the organization relating to the satisfaction felt by team members.

Effective team implementation can increase motivation to work and individual satisfaction (Griffin, Petterson and West, 2001). (Campion, Medsker and Higgs, 1993) stated that job satisfaction of team members is determined by several factors including the composition of the team, the processes that occur in the team, and the nature of the work done in the team. Through teamwork the negative relationship between technostress and job satisfaction can be reduced. (Wang, Shu and TU, 2008) and (Kayastha, Adhikary and Krishnamurthy, 2012) found that decreasing the level of technostress on employees will have an impact on job satisfaction that is increasingly high. Referring to the explanation, it can be concluded that teamwork is predicted to weaken the negative relationship between technostress and job satisfaction .

H5:Teamwork moderates the the effect of technostress and job satisfaction

So, based on the hypothesis development discussion above, the research paradigm can be formulated as follows.

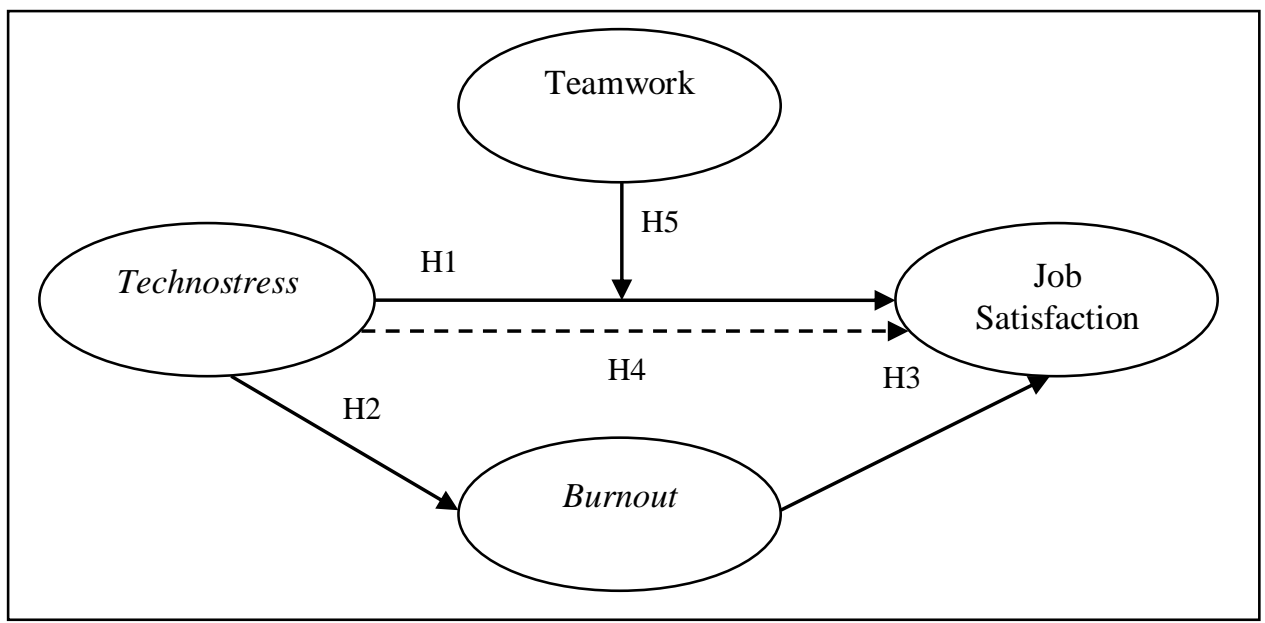

Figure 1. Research Paradigm

Hypotheses set :

H1: Technostress has a negative effect on job satisfaction

H2: Technostress has a positive effect on burnout

H3: Burnout has a negative effect on job satisfaction

H4: Burnout mediates the influence between technostress and job satisfaction

H5: Teamwork moderates the effect of technostress and job satisfaction

\section{METHOD}

This research uses a questionnaire to collect the primary data. The population of this study is all Bank Indonesia employees. The selected sample is Bank Indonesia employees who 


\section{International Journal of Business Management and Economic Review}

Vol. 3, No. 01; 2020

ISSN: 2581-4664

have been working more than two years and use information technology systems both software developed by BI and hardware such as smart phones and laptops. The sampling technique used is random sampling. Each population in the sample frame has the same opportunity to be elected as a respondent.

The instrument used to measure job satisfaction variable uses the Minnestoa Satisfaction Questionnaire (MSN) developed by (Weiss, Dawis and England, 1967). The measurement instrument contains 20 (twenty) items of statements on a scale of 1-5 (very dissatisfied until very satisfied). Technostress variableis measured using instruments developed by (Ragu-Nathan et al., 2008) with 23 statement items and divided into five dimensions, namely techno invasion, techno overload, techno complexity, techno uncertainty, and techno insecurity. To measure the burnout variable, researchers used an instrument that developed by the Maslach Burnout Inventory General Survey (MBI-GS) (Maslach and Jackson, 1981) which contains 22 statement items with measuring scale using a Likert scale of 1-5. Finally, researchers use an instrument developed by (Kathuria and Davis, 2001) to measure teamwork with six Likert scale statement items of 1-5 (strongly disagree to strongly agree).

To analyze the data, the researcher uses SEM PLS with the application of Warp PLS version 6. The use of SEM PLS is quite appropriate for several reasons, first, the purpose of this study is to test / explore a new model with an expansion of existing theories. Second, the structural model that is built is relatively complex. There are constructs of various types such as first order construct and second order construct. Third, SEM PLS is reliable enough to test the amount of data in small sets and abnormal data. PLS SEM testing uses a two step approachby the (Baron and Kenny, 1986) and Sobel test to test the effects of mediation.

\section{RESULTS}

\section{General Description of Respondents}

The number of responses collected is 174. Based on the established criteria, which are Bank Indonesia employees who have been working for more thantwo years and uses at least one information technology system at work, it is found that the sample meets these criteria and all data can be used.

Based on the data obtained, the amount of respondent using hardware technology in the form of laptopis 167 (96\%), cell phoneis 90 (51.7\%), and tablet is 11 (6.3\%). Meanwhile, the amount of respondent using ERP software is 100 (57.5\%), HRIS is 134 (77\%), CBS is 12 $(6.9 \%)$, FOMOBO is $2(1.1 \%)$, EDW is 24 (13.8\%), Messaging media is $120(69 \%)$, e-mail is 144 (82.8), and other BI information systems is $89(51.1 \%)$. 


\section{International Journal of Business Management and Economic Review}

Vol. 3, No. 01; 2020

ISSN: 2581-4664

Table 1. Respomdents Using the ICT Devices

\begin{tabular}{|c|c|c|c|c|}
\hline \multirow{2}{*}{ No } & \multicolumn{2}{|l|}{ Information } & \multirow{2}{*}{$\begin{array}{l}\text { Number of } \\
\text { Respondents }\end{array}$} & \multirow{2}{*}{ Percentage } \\
\hline & Characteristics & Classification & & \\
\hline \multirow{3}{*}{1} & \multirow{3}{*}{ Hardware } & Laptop & 167 & $96 \%$ \\
\hline & & Handphone & 90 & $52 \%$ \\
\hline & & Tablet & 11 & $6 \%$ \\
\hline \multirow{8}{*}{2} & \multirow{8}{*}{ Software } & ERP & 100 & $57 \%$ \\
\hline & & HRIS & 134 & $77 \%$ \\
\hline & & CBS & 12 & $7 \%$ \\
\hline & & FOMOBO & 2 & $1 \%$ \\
\hline & & EDW & 24 & $14 \%$ \\
\hline & & Online Messaging Media & 120 & $69 \%$ \\
\hline & & Surel & 144 & $83 \%$ \\
\hline & & EDW & 89 & $51 \%$ \\
\hline
\end{tabular}

Furthermore, the analysis of data obtained shows that the majority of respondents are male $(120 \%)$ and female $(54 \%)$. The age of respondents is quite evenly distributed, with ages 35 46 dominating with a response of $63(36 \%)$. In terms of education, the majority of respondents have undergraduate education (58\%) and followed by respondents with undergraduate (34\%). The working period of the majority of respondents is more than 10 years $(61 \%)$. The rank of respondentparticipating in this survey varies from the rank of assistant / staff as much as $31 \%$, Assistant Manager / Manager 40\%, Assistant Director / Dep. Director 29\%, Director / Dir. Executive $1 \%$.Meanwhile, the distribution of respondents is also quite balanced with a response rate of $57 \%$ of respondents serving in the Representative Office and $43 \%$ serving in the Central Office. Finally, the respondent of job family is evenly distributed in the field of monetary job families, payment systems, enablers, and financial system stability.

Next, this research is analyzed the responses of the answers from the questionnaire using the Respondent Perception Index (IPR) method. This index is to measure the level of respondent perceptions to all variables. Based on the result, the IPR for variable technostress creators is 64 (enough / neutral), job satisfaction 74 (satisfied), burnout 58 (enough / neutral), and teamwork 79 (agree). The index shows that respondents experienced a level of pressure on the use of technology and experienced emotional and physical exhaustion at a sufficient level. Meanwhile, respondents perceive job satisfaction and teamwork at a high level. The following table describes in detail about the Respondent Perception Index analysis. 


\section{International Journal of Business Management and Economic Review}

Vol. 3, No. 01; 2020

ISSN: 2581-4664

\section{Table 2. Respondent Perception Index}

\begin{tabular}{|l|l|l|}
\hline Variable & IPR & Criteria \\
\hline Technostress Creator & 64 & Fair / neutral \\
\hline Job satisfaction & 74 & Agree \\
\hline Burnout & 58 & Fair / neutral \\
\hline Teamwork & 79 & Agree \\
\hline
\end{tabular}

\section{Validity and Reliability Test}

Convergent validity test result shows that the value of Average Variance Extracted (AVE) and Communality for all variables is above (>) 0.50. This means that the data collected can explain more than $50 \%$ of the variance that occurs in variables. Based on the result of convergent validity testing, several indicators must be issued as a measure of burnout variables (B15, B16, B17, B18, B, 19, B20, B21, and B22) because the factor loading value is less $(<)$ than 0.4-0.7.

Meanwhile, the indicator that is still used has a factor loading value of 0.4 to 0.7 . These parameters are used based on the recommended procedure of Hair et al (2013) that the removal of the indicator can be done at a factor loading below 0.7 if it does not increase AVE and composite reliability above the limit. Thus, indicators with factor loading between 0.4-0.7 are maintained.

Furthermore, validity testing also looks at the level of correlation of indicators both in the construct and with other constructs or known as discriminant validity. The discriminant validity test can be seen from two output scores, namely (1) comparing the roots of AVE of a construct that must be higher than the correlation between constructs, (2) comparing the scores of cross loading indicators between constructs.

SEM performance result shows that the AVE root scores of all variables that are technostress, burnout, job satisfaction, and teamwork have a high AVE root score in its construct compared to other constructs. The root values of AVE on the variable techno-overload (0.734), techno invasion (0.898), techno complexity (0.784), techno insecurity (0.736), techno uncertainty (0.850), job satisfaction (0.724), burnout (0.769), teamwork (0.878) are greater than the other constructs. Another parameter is by comparing the cross loading scores between the indicators and each construct tested. The test results show that all indicators have a greater cross loading score on the construct compared to other constructs.

The test result shows that the Cronbach's alpha score and composite reliability of all variables above 0.7 (see table 3). These result indicates that the measuring instrument used has met the element of reliability and can be relied upon to measure the construct. 
International Journal of Business Management and Economic Review

Vol. 3, No. 01; 2020

ISSN: 2581-4664

Table 3. Cronbach's Alpha Score and Composite Reliability

\begin{tabular}{|l|l|l|}
\hline Variable & Composite reliability & Cronbach's alpha \\
\hline TO & 0.853 & 0.784 \\
\hline TI & 0.944 & 0.920 \\
\hline TC & 0.887 & 0.838 \\
\hline TS & 0.854 & 0.784 \\
\hline TU & 0.912 & 0.871 \\
\hline KK & 0.956 & 0.951 \\
\hline BO & 0.952 & 0.945 \\
\hline KT & 0.953 & 0.940 \\
\hline
\end{tabular}

\section{Hypotgesis Test Result}

Structural model testing is carried out through three stages, first testing the direct relationship between the predictor variable (technostress creator) and the criterion variable (job satisfaction). Second, indirect testing involves the contingency variables (mediation), namely the role of burnout as a mediator. Third, the test involves contingency variables (moderation), i.e. teamwork and testing model. The second and third stages of testing can be done if it is found the effect of the relationship between the main variables (Baron and Kenny, 1986).

In the first stage test,it provides the coefficients and significances of the direct effects. The test result (see table 4 Panel A) shows that technostress creator has a negative effect on job satisfaction (coefficient $\left.=-0.144 ; \mathrm{p}<0.05 ; \mathrm{R}^{2}=0.021\right)$. Thus, hypothesis $1(\mathrm{H} 1)$ has proven that technostress has a negative effect on job satisfaction.

Next analysis is carried out by involving the burnout variable. The test result (see table 4 Panel B) shows that technostress has a positive effectonimproving burnout (coefficient $=0.607$, $\left.\mathrm{p}<0.01, \mathrm{R}^{2}=0.369\right)$. Then the hypothesis $2(\mathrm{H} 2)$ is proven that technostress effects burnout positively. Otherwise, the result shows burnout has a negative effects on job satisfaction (coefficient $\left.=-0.461, \mathrm{p}<0.01, \mathrm{R}^{2}=0.209\right)$. So the hypothesis $3(\mathrm{H} 3)$ is proven that burnout effects job satisfaction negatively.

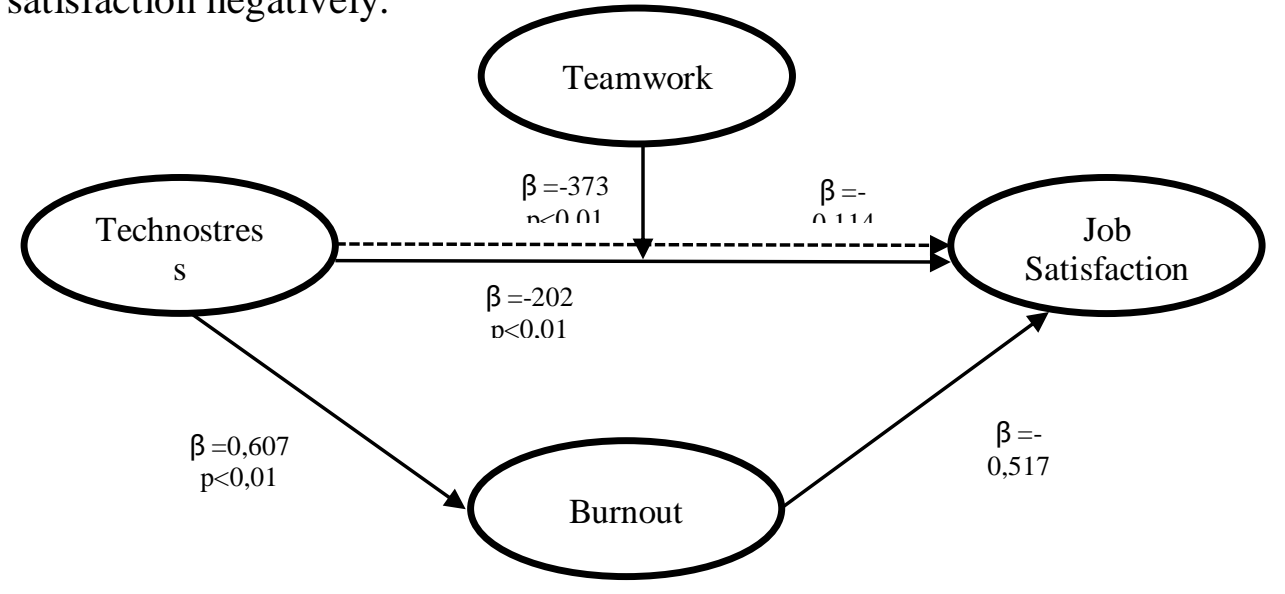

Figure 2. Model Test Result 


\section{International Journal of Business Management and Economic Review}

Vol. 3, No. 01; 2020

ISSN: 2581-4664

Then, the test result also finds the evidence that the variable burnout fully mediates the effect of technostress on job satisfaction. This conclusion is explained by the effect of technostress on job satisfaction becomes insignificant $(p=0.16$, with coefficient value $=0.073$ ), when the burnout variable is involved in testing. Thus, the hypothesis 4 (H4) which suggests that burnout mediates the effect of technostress on supported job satisfaction is accepted.

For the moderation test(see Table 4 Panel C), the coefficient value of the influence of the

\begin{tabular}{|lll|}
\hline Panel C. Moderation Effect Model & & \\
\cline { 2 - 3 } & Path to & \\
\hline Technostress Creator & Job Satisfaction & Kepuasan Kerja \\
\hline Burnout & $0.607^{* * *}$ & $-0.202^{* * *}$ \\
\hline Teamwork * Technostress Creators & & $-0.517^{* * *}$ \\
\hline $\mathrm{R}^{2}$ & 0.369 & $-0.373^{* * *}$ \\
\hline
\end{tabular}

interaction variable between technostress and job satisfaction (techsress $* \mathrm{KT}$ ) is -0.373 , with $\mathrm{p}$ value $<0.001(\mathrm{R} 2=0.195)$. This affirms that the hypothesis 5 (H5) the involvement of teamwork is able to moderate (reduce) the negative influence of technostress on job satisfaction. A summary of the test results can be seen in the following table.

\section{Table 4. PLS Test Results (path coefficient, $t$-statistic,dan $\mathbf{R}^{\mathbf{2}}$ )}

\begin{tabular}{|ll|}
\hline Panel A. Direct Influence & \\
\hline Variable & Path to \\
\hline Technostress Creator & Job satisfaction \\
\hline $\mathrm{R}^{2}$ & $-0.144^{* *}$ \\
\hline
\end{tabular}

\begin{tabular}{|lll|}
\hline Panel B. Indirect Effect of Burnout as a Mediation \\
\hline Variable & Path to & \\
\cline { 2 - 3 } & Burnout & Job satisfaction \\
\hline Technostress Creator & $0.607 * * *$ & 0.073 \\
\hline Burnout & & $-0.461 * * *$ \\
\hline $\mathrm{R}^{2}$ & 0.369 & 0.209 \\
$* * * \mathrm{p}<0.01$ (one-tailed). & & \\
$* * \mathrm{p}<0.05$. & & \\
$* \mathrm{p}<0.10$. & & \\
\end{tabular}

After testing the hypothesis, the next is analyzing the fit model of the research. SEM PLS test result produces several model fit parameters such as Average R-squared (ARS), average variance inflation factor (AVIF), average patch coefficient (APC), Tenenhous Goodness of Fit (GoF), etc. The following table summarizes the results of testing the model fit. 


\section{International Journal of Business Management and Economic Review}

Vol. 3, No. 01; 2020

ISSN: 2581-4664

\section{Table 5. Model Fit Test Result}

\begin{tabular}{|l|l|l|l|}
\hline Parameter & Indicator & $0.282(\mathrm{p}<0.001)$ & Fulfilled \\
\hline ARS & Signifikan $\mathrm{p}<0.001$ & 1.789 & Fulfilled (ideal) \\
\hline AVIF & Ideal $<3.3$ & $0.425(\mathrm{p}<0.001)$ & Fulfilled \\
\hline APC & Signifikan $\mathrm{p}<0.001$ & Big \\
\hline GoF & $\begin{array}{l}>0.1(\text { Small }) ; \\
(\text { medium }) ;>0.36(\text { Big })\end{array}$ & 0.405 & 0.25 \\
\hline
\end{tabular}

Table 5 shows that all model fit indicators are fulfilled with an ARS value of 0.282 with significant value of $p<0.001$. The AVIF indicator shows that the mean value of the variance produced by the model is 1.789 below 3.3, which means it is an ideal AVIF value. Furthermore, the APC value of 0.425 with a significance of $p<0.001$ is fulfilled. While the GoF Tenenhaus value of 0.405 means the research model is able to explain the variance well.

Next, the researcher analyzes the effect of the burnout mediation effect using the Baron \& Kenny approach and the Sobel test approach and calculates the total value of the indirect effect. The Sobel calculation resultusing a calculator shows a Z score of 5.86 (p-value <0.01). These result confirms the two step approach testing (Baron and Kenny, 1986) where the mediation variable (burnout) has a significant effect on the effect of technostress on job satisfaction. Then, the researcher analyzes the direct and indirect effect calculations to calculate the total effect of the variable. The following table summarizes the calculation of the total effect of variables.

\section{Table 6. Total Effect}

\begin{tabular}{|l|l|l|l|}
\hline Independent Variable & Dependent Variable & Direct Effect & Indirect Effect \\
\hline Technostress & Job Satisfaction & $-0.144^{* *}$ & \\
\hline Burnout Out & & $-0.517 * * *$ & $0.313^{*}$ \\
\hline$* \mathrm{TS}-\mathrm{BO}-\mathrm{KK}=$ & $\begin{array}{l}\text { Total Effect }=0.607 \times- \\
0.517=\mathbf{0 . 3 1 3}\end{array}$ & & \\
& 0 & & \\
\hline
\end{tabular}

Then the types of interaction of moderating variableis analyzed by testing in stages. Testing is done by examining the relationship with independent and dependent variables. The result of teamwork has a significant influence on technostress (coefficient $=-0.22 ; \mathrm{p}<0.01$ ) and job satisfaction (coefficient $=0.57 ; \mathrm{p}<0.01$ ). In accordance with the concept described in the previous chapter, if the interaction variable is significantly related to the independent and dependent variables then the variable is called Quasi Moderator.

\section{CONCLUSION}

The result shows that technostress has a negative effect on job satisfaction, technostress has a positive effect on burnout, burnout has a negative effect on job satisfaction, burnout mediates the influence between technostress and job satisfaction, and teamwork moderates the effect of technostress and job satisfaction. These results figure that the higher psychological pressure 


\section{International Journal of Business Management and Economic Review}

Vol. 3, No. 01; 2020

ISSN: 2581-4664

faced by individuals due to the use of technology can reduce the level of individual job satisfaction. This result also means that individuals who experience psychological pressure due to the use of technology have an impact on increasing mental and psychological fatigue (burnout) of individuals. Mental and psychological fatigue cause individuals to be apathetic and reduce their level of satisfaction with the work done. But then, teamwork can reduce the negative effect of technostress on job satisfaction.

These findings streghten the previous theories especially the causality ones. It contributes to the realm of science especially in human resource management field, and can be a reference for practical managers especially in the Bank Indonesia as the research object. The originality lies in the combination of causality models, uses SEM-PLS as an analysis tool, and the new object. The limitation resides in the amount of variables that are only three, with one object.

\section{REFERENCES}

Åborg, C. and Billing, A. (2003) 'Health effects of the Paperless Office-evaluations of the introduction of electronic document handling systems', Behaviour and Information Technology, 22(6), pp. 389-396. doi: DOI: 10.1080/01449290310001624338.

Affleck, M. A. (1996) 'Burnout among bibliographic instruction librarians', Library \& Information Science Research, 18(2), pp. 165-183. doi: https://doi.org/10.1016/S07408188(96)90018-3.

Alleyne, D. C. (2012) A quantitative model examining the effects of technostress in professionals. Walden University. doi: 978-1-267-63855-7.

Amoako-Gyampah, K. (2007) 'Perceived usefulness, user involvement and behavioral intention: An empirical study of ERP implementation', Computers in Human Behavior2, 23(3), pp. 1232-1248. doi: DOI: 10.1016/j.chb.2004.12.002.

Amoo, G. and Fatoye, F. O. (2008) 'Burnout in South-Western Nigeria: A Preliminary Report among Nurses and Teachers', Ife Psychologia, 16(2).

Aydogdu, S. and Aşıkgil, B. (2011) 'An Empirical Study of the Relationship Among Job Satisfaction, Organizational Commitment and Turnover Intention', International Review of Management and Marketing, 1(3), pp. 43-53. Available at: www.econjournals.com.

Ayyagari, R., Grover, V. and Purvis, R. (2011) 'Technostress: Technological Antecedents and Implications', MIS Quarterly, 35(4), pp. 831-858.

Baron, R. M. and Kenny, D. A. (1986) 'The moderator-mediator variable distinction in social psychological research: Conceptual, strategic, and statistical considerations.', Journal of personality and social psychology. American Psychological Association, 51(6), p. 1173.

Beaudry, A. and Pinsonneault, A. (2010) 'The Other Side of Acceptance: Studying the Direct and Indirect Effects of Emotions on Information Technology Use', MIS Quarterly, 34(4), pp. 689-710. doi: DOI: 10.2307/25750701.

Bhanugopan, R. and Fish, A. (2006) 'An empirical investigation of job burnout among expatriates', Personnel Review, 35(4), pp. 449-468. doi: https://doi.org/10.1108/00483480610670607.

Brillhart, P. . (2004) 'Technostress in the Workplace: Managing Stress in the Electronic Workplace', Journal of American Academy of Business, 5, pp. 302-307.

Brod, C. (1982) 'Managing Technostress: Optimizing the Use of Computer Technology', Personnel Journal, 61(10). 


\section{International Journal of Business Management and Economic Review}

Vol. 3, No. 01; 2020

ISSN: 2581-4664

Brod, C. (1984) Technostress: The Human Cost of the Computer Revolution. United States: Addison-Wesley.

Brookings, J. B. et al. (1985) 'Self-Reported Job Burnout Among Female Human Service Professionals', Journal of Occupational Behaviour, 6(2), pp. 143-150. Available at: https://www.jstor.org/stable/3000248.

Brooks, S. and Califf, C. (2017) 'Social media-induced technostress: Its impact on the job performance of it professionals and the moderating role of job characteristics', Computer Networks, 114, pp. 143-153. doi: https://doi.org/10.1016/j.comnet.2016.08.020.

Campion, M. A., Medsker, G. J. and Higgs, A. C. (1993) 'Relations Between Work Group Characteristics And Effectiveness: Implications For Designing Effective Work Groups', Personnel Psychology, 46, pp. 823-850. doi: https://doi.org/10.1111/j.17446570.1993.tb01571.x.

Chang, H. H. (2006) 'Technical and management perceptions of enterprise information system importance, implementation and benefits', Information Systems Journal, 16(3), pp. 263292. doi: https://doi.org/10.1111/j.1365-2575.2006.00217.x.

Chen, L. (2015) 'Validating the Technostress Instrument Using a Sample of Chinese Knowledge Workers', Journal of International Technology and Information Management, 24(1).

Delarue, A. et al. (2007) 'Teamworking and organizational performance: A review of survey-based research', International Journal of Management Reviews, 10(2), pp. 127148. doi: https://doi.org/10.1111/j.1468-2370.2007.00227.x.

Francis, olalude oluwole and Popoola, S. O. (2013) 'Work Values, Achievement Motivation and Technostress as Determinants of Job Burnout among Library Personnel in Determinants of Job Burnout among Library Personnel in Automated Federal University Libraries in Nigeria Automated Federal University Libraries ', Library Philosophy and Practice (ejournal), 919. Available at: https://digitalcommons.unl.edu/libphilprac/919.

Freudenberger, H. J. (1974) 'Staff Burn-Out', Journal of Social, 30(1), pp. 159-165. doi: https://doi.org/10.1111/j.1540-4560.1974.tb00706.x.

Fuglseth, A. M. and Sørebø, Ø. (2014) 'The effects of technostress within the context of employee use of ICT', Computers in Human Behavior, 40, pp. 161-170. doi: https://doi.org/10.1016/j.chb.2014.07.040.

Furnham, A. et al. (2002) 'Do personality factors predict job satisfaction?', Personality and Individual Differences, 33, pp. 1325-1342. doi: DOI: 10.1016/S0191-8869(02)00016-8.

Galluch, P. S., Grover, V. and Thatcher, J. B. (2015) 'Interrupting the Workplace: Examining Stressors in an Information Technology Context', Journal of the Association for Information Systems, 16(1), pp. 1-47. doi: 10.17705/1 jais.00387.

Griffin, M. A., Petterson, M. G. and West, M. A. (2001) 'Job satisfaction and teamwork: the role of supervisor support', Journal of Organizational Behavior, 22, pp. 537-550. doi: https://doi.org/10.1002/job.101.

Hackman, J. R. (1989) Groups That Work (and Those That Don't): Creating Conditions for Effective Teamwork. 1st edn. San Francisco: Jossey-Bass.

Halbesleben, J. R. B. and Buckley, M. R. (2004) 'Burnout in Organizational Life', Journal of Management, 30(6), pp. 859-879. doi: https://doi:10.1016/j.jm.2004.06.004.

Herzberg, F. (1974) 'Motivation-hygiene profiles: Pinpointing what ails the organization', Organizational Dynamics, 3(2), pp. 18-29. doi: https://doi.org/10.1016/0090- 


\section{International Journal of Business Management and Economic Review}

Vol. 3, No. 01; 2020

ISSN: 2581-4664

2616(74)90007-2.

Ibrahim, M. and Yusra (2016) 'Work-Family Conflict and Job Satisfaction: The Mediating Role of Person-Organization Fit Study on Employees of The BRI Aceh Region', The South East Asian Journal of Management, 10(2), pp. 173-182. doi: https://doi/org/10.21002/seam.v10i2.7734.

Janz, B. D., Colquitt, J. A. and Noe, R. A. (1997) 'Knowledge worker team effectiveness: The role of autonomy, interdependence, team development, and contextual support variables', Personnel Psychologyl, 50(4), pp. 877-904. doi: https://doi.org/10.1111/j.17446570.1997.tb01486.x.

Kathuria, R. and Davis, E. B. (2001) 'Quality And Work Force Management Practices: The Managerial Performance Implication', Production And Operations Management, 10(4), pp. 460-477. doi: https://doi.org/10.1111/j.1937-5956.2001.tb00087.x.

Kayastha, R., Adhikary, P. R. and Krishnamurthy, V. (2012) 'Correlates of occupational stress among executive officers of Nepal', IJRRAS, 12(1), pp. 101-106.

Khalatbari, J., Ghorbanshiroudi, S. and Firouzbakhsh, M. (2013) 'Correlation of Job Stress, Job Satisfaction, Job Motivation and Burnout and Feeling Stress', Procedia - Social and Behavioral Sciences, 84(9), pp. 860-863. doi: https://doi.org/10.1016/j.sbspro.2013.06.662.

Khallash, S. and Kruse, M. (2012) 'The Future of Work and Work-Life Balance 2025', Futures, 44, pp. 678-686. doi: https://doi.org/10.1016/j.futures.2012.04.007.

Khamisa, N. et al. (2017) 'Effect of personal and work stress on burnout, job satisfaction and general health of hospital nurses in South Africa', Health SA Gesondheid, 22, pp. 252-258. doi: https://doi.org/10.1016/j.hsag.2016.10.001.

Khan, A., Rehman, H. ur and Réhman, S. ur (2013) 'An Empirical Analysis of Correlation Between Technostress and Job Satisfaction: A Case of KPK, Pakistan', Pakistan Journal of Information Management and Libraries, 14(1).

Khedhaouria, A. and Cucchi, A. (2019) 'Technostress creators, personality traits, and job burnout: A fuzzy-set configurational analysis', Journal of Business Research, 101, pp. 349-361. doi: https://doi.org/10.1016/j.jbusres.2019.04.029.

Khuong, M. N. and Tien, B. D. (2013) 'Factors influencing employee loyalty directly and indirectly through job satisfaction - A study of banking sector in Ho Chi Minh City', International Journal of Current Research and Academic Review, 4(1), pp. 81-95.

Klassen, R. M., Usher, E. L. and Bong, M. (2010) 'Teachers' Collective Efficacy, Job Satisfaction, and Job Stress in Cross-Cultural Context', The Journal of Experimental Education, 78(4), pp. 464-486. doi: https://doi.org/10.1080/00220970903292975.

Kupersmith, J. (1992) 'Technostress and the Reference Librarian', RSR Reference Services Review, 20(2), pp. 7-14.

Lazarus, R. S. (1966) Psychological stress and the coping process. New York: McGraw-Hill.

Mafini, C. and Pooe, D. R. I. (2013) 'The relationship between employee satisfaction and organisational performance: Evidence from a South African government department', $S A$ Journal of Industrial Psychology, 39(1). doi: https://doi.org/10.4102/sajip.v39i1.1090.

Marhayani, Musnadi, S. and Ibrahim, M. (2019) 'Effect Of Competence And Employee Commitment To Employee Performance: Job Satisfaction As A Mediator (Study On Watering Office Of Aceh Province)', International Journal of Business Management and 


\section{International Journal of Business Management and Economic Review}

Vol. 3, No. 01; 2020

ISSN: 2581-4664

$\begin{array}{llllll}\text { Economic } & \text { Review, } & \text { 2(1), } & \text { pp. }\end{array}$

http://ijbmer.org/uploads2019/BMER_2_75.pdf.

Maslach, C. and Jackson, S. E. (1981) 'The measurement of experienced burnout', Journal of Occupational Behaviour, 2, pp. 99-113. doi: https://doi.org/10.1002/job.4030020205.

Maslach, C., Schaufeli, W. B. and Leiter, M. P. (2001) 'Job Burnout', Annual Review of Psychology, 52, pp. 397-422. doi: https://doi.org/10.1146/annurev.psych.52.1.397.

Morris, M. G. and Venkatesh, V. (2010) 'Job Characteristics and Job Satisfaction: Understanding the Role of Enterprise Resource Planning System Implementation', MIS Quarterly, 34(1), pp. 143-161. doi: https://DOI: 10.2307/20721418.

Muhammadsyah, Nasir and Faisal (2019) 'Does Job Satisfaction Mediate Effects of Organizational Commitments, Culture and Staff's Empowerment on the Islamic Bankers' Performance?', East African Scholars Journal of Economics, Business and Management, 2(6), pp. 279-287. Available at: https://www.easpublisher.com.

Nickerson, A. B. and Nagle, R. J. (2005) 'Parent and Peer Attachment in Late Childhood and Early Adolescence', The Journal of Adoslesennce, 25(2), pp. 223-249. doi: https://doi.org/10.1177/0272431604274174.

Parker, S. and Wall, T. (1998) Job and Work Design: Organizing Work to Promote Well-Being and Effectiveness. London: SAGE Publications, Inc. doi: http://dx.doi.org/10.4135/9781452231518.

Patience, S. (2012) Preventing burnout, The nation Sunday, January 08,. Available at: https://issuu.com.

Ragu-Nathan, T. S. et al. (2008) 'The Consequences of Technostress for End Users in Organizations: Conceptual Development and Empirical Validation', Information Systems Research, 19(4). doi: https://doi.org/10.1287/isre.1070.0165.

Rhodes, M. L. et al. (2011) Public management and complexity theory: Richer decision-making in public service. London: Taylor and Francis.

Riedl, R. et al. (2013) 'Computer Breakdown as a Stress Factor during Task Completion under Time Pressure: Identifying Gender Differences Based on Skin Conductance', Advances in Human-Computer Interaction, pp. 1-8. doi: http://dx.doi.org/10.1155/2013/420169.

Rosenberg, T. and Pace, M. (2006) 'Burnout among mental health professionals: special considerations for the marriage and family therapist', Journal of Marital and Family Therapy, 32(1), pp. 87-99. doi: https://DOI:10.1111/j.1752-0606.2006.tb01590.x.

Saganuwan, M. U., Ismail, W. K. W. and Ahmad, U. N. U. (2015) 'Conceptual Framework: AIS Technostress and Its Effect on Professionals' Job Outcomes', Asian Social Science, 11(5), pp. 97-107. doi: http://dx.doi.org/10.5539/ass.v11n5p97.

Sebanz, N., Bekkering, H. and Knoblich, G. "̈ther (2006) 'Joint action: bodies and mindsmoving together', TRENDS in Cognitive Sciences, 10(2), pp. 70-76. doi: oi:10.1016/j.tics.

Srivastava, S. C., Chandra, S. and Shirish, A. (2015) 'Technostress creators and job outcomes: theorising the moderating influence of personality traits', Information System Journal, 25, pp. 355-401. doi: https://doi.org/10.1111/isj.12067.

Suh, A. and Lee, J. (2017) 'Understanding teleworkers' technostress and its influence on job satisfaction', Internet Research, 27(1), pp. 140-159. doi: https://doi.org/10.1108/IntR-062015-0181.

Suh, B. and Han, I. (2003) 'The Impact of Customer Trust and Perception of Security Control on 


\section{International Journal of Business Management and Economic Review}

Vol. 3, No. 01; 2020

ISSN: 2581-4664

the Acceptance of Electronic Commerce', International Journal of Electronic Commerce, 7(3), pp. 135-161. doi: https://doi.org/10.1080/10864415.2003.11044270.

Sumer, H. C. and Knight, P. A. (2001) 'How do people with different attachment styles balance work and family? A personality perspective on work-family linkage', Journal of Applied Psychology, 86(4), pp. 653-663. doi: DOI: 10.1037//0021-9010.86.4.653.

Sundstrom, E., Meuse, K. P. De and Futrell, D. (1990) 'Work Teams: Applications and Effectiveness', American Psychologist, 45(2), pp. 120-133. doi: DOI: 10.1037/0003066X.45.2.120.

Tarafdar, M. et al. (2007) 'The Impact of Technostress on Role Stress and Productivity', Journal of Management Information Systems, 24(1), pp. 301-328. doi: doi.org/10.2753/MIS07421222240109 .

Tarafdar, M. et al. (2011) 'Crossing to the Dark Side: Examining Creators, Outcomes, and Inhibitors of Technostress', Communications of the ACM, 54(9), pp. 113-120. doi: DOI: 10.1145/1995376.1995403.

Tarafdar, M., Cooper, C. L. and Stich, J. (2017) 'The technostress trifecta - techno eustress, techno distress and design: Theoretical directions and an agenda for research', Research Opinion Wiley, 29, pp. 6-42. doi: https://doi.org/10.1111/isj.12169.

Tarafdar, M., Pullins, E. B. and Ragu-Nathan, T. S. (2014) 'Technostress: negative effect on performance and possible mitigations', Information System Journal, 25(2), pp. 1-30. doi: DOI:10.1111/isj.12042.

Tarafdar, M., Tu, Q. and Ragu-Nathan, T. S. (2014) 'Impact of Technostress on End-User Satisfaction and Performance', Journal of Management Information Systems, 27(3), pp. 303-334. doi: https://doi.org/10.2753/MIS0742-1222270311.

Tarcan, M. et al. (2017) 'An analysis of the relationship between burnout, socio-demographic and workplace factors and job satisfaction among emergency department health professionals', Applied Nursing Research, 34, pp. 40-47. doi: https://doi.org/10.1016/j.apnr.2017.02.011.

Tu, Q., Wang, K. and Shu, Q. (2005) 'Computer-Related Technostress in China', Communication of the ACM, 48(4), pp. 77-81. doi: 10.1145/1053291.1053323.

Wall, T. D. et al. (1986) 'Outcomes of Autonomous Workgroups: A Long-Term Field Experiment', The Academy of Management Journal, 29(2), pp. 280-304. doi: DOI: $10.2307 / 256189$.

Wang, K., Shu, Q. and TU, Q. (2008) 'Technostress under different organizational environments: An empirical investigation', Computers in Human Behavior, 24(6), pp. 3002-3013. doi: https://doi.org/10.1016/j.chb.2008.05.007.

Wang, W., Kakhki, M. D. and Uppala, V. (2017) 'The Interaction Effect of Technostress and Non-Technological Stress on Employees' Performance The Interaction Effect of Technostress and Non-Technological Stress on Employees' Performance', Interaction Effect of Technostress and Non-Technological Stress.

Wani, C. E., Adam, M. and Majid, M. S. A. (2018) 'The Mediated Effect of Job Satisfaction on the Relationships between Leadership Effectiveness, Organizational Support, Working Environment and Ability: The Case of State-Owned Electricity Company in Indonesia', IOSR Journal of Business and Management (IOSR-JBM), 20(9), pp. 68-74. doi: https://doi.org/10.9790/487X-2009066874. 
International Journal of Business Management and Economic Review

Vol. 3, No. 01; 2020

ISSN: 2581-4664

Weil, M. M. and Rosen, L. D. (1997) TechnoStress: Coping with Technology@Work@Home @ Play. New Jersey: Wiley.

Weil, M. M., Rosen, L. D. and Wugalter, S. E. (1990) 'The etiology of computerphobia', Computers in Human Behavior, 6(4), pp. 361-379. doi: https://doi.org/10.1016/07475632(90)90014-8.

Weiss, D. J., Dawis, R. V. and England, G. W. (1967) 'Manual for the Minnesota Satisfaction Questionnaire', Minnesota Studies in Vocational Rehabilitation, 22(120).

Yang, J.-T. (2010) 'Antecedents and consequences of job satisfaction in the hotel industry', International Journal of Hospitality Management, 29(4), pp. 609-619. doi: https://doi.org/10.1016/j.ijhm.2009.11.002.

Yukl, G. (2006) Leadership in Organizations. 6th edn. United States: Pearson Prentice Hall. 